\title{
Health education interventional programme and its impact on adolescent students
}

\author{
Rupali Salve ${ }^{1}$, Anjali Kher ${ }^{2}$, Richa Chaudhary ${ }^{3}$, Keerti Swarnakar ${ }^{2}$, Sarika Gaikawad ${ }^{4}$, Punam Uke ${ }^{4}$, \\ Bhavna Lakhkar ${ }^{2}$
}

Sri Lanka Journal of Child Health, 2022; 51(1): 69-74

DOI: http://dx.doi.org/10.4038/sljch.v51i1.9998

\begin{abstract}
Introduction: In India there are about 242 million adolescents accounting for $22 \%$ of its population. It is important to give the adolescents information regarding the physical, sexual, psychological and social changes they undergo during this period.
\end{abstract}

Objectives: Assessing the effectiveness of a health education interventional programme on improving the knowledge of adolescent students about nutrition, reproductive health, sexual and substance abuse and psychosocial problems.

Method: Present study was conducted on students of $5^{\text {th }}$ to $9^{\text {th }}$ standard (10 -16-year age group) of Hindi medium school in rural central India. It was a prospective interventional study and a health education interventional programme was conducted. A total of 401 adolescents were included in study. A pre-test was conducted followed by health education and awareness workshops based on a pre-designed, pre-validated teaching module, followed by a focus group discussion of girls and boys in different groups and a post-test at the end. Data in the form of pre- and post-test questionnaire and notes taken during focus group discussion were collected and analysed using STATA 10 version software and for qualitative data, content analysis was done.

Results: Out of the 401 adolescents, $80 \%$ were in 12-14 year age group and had almost equal gender distribution. In knowledge and perception regarding

\footnotetext{
${ }_{1}^{1}$ Senior Resident, ${ }^{2}$ Professor, ${ }^{3}$ Associate Professor, ${ }^{4}$ Assistant Professor, Department of Paediatrics, Jawaharlal Nehru Medical College and Acharya Vinoba Bhave Rural Hospital, Datta Meghe Institute of Medical Sciences, Sawangi (M), Wardha, Maharashtra, India

*Correspondence: anjalimkher@gmail.com$$
\text { iD. }
$$$$
\text { https//orcid.org/ 0000-0003-0214-6954 }
$$

(Received on 23 January 2021: Accepted after revision on 31 March 2021)

The authors declare that there are no conflicts of interest

Personal funding was used for the project.

Open Access Article published under the Creative

Commons Attribution CC-BY (c) (i) License nutrition and health, body and self-image, menstrual hygiene and reproductive health, awareness about sexual abuse and psychological problems of adolescence, there was statistically significant improvement $(\mathrm{p}=0.000)$ after the educational intervention. Majority of the adolescents thought that there was a need for proper guidance of adolescents. On qualitative analysis, it was seen that adolescents had knowledge of the bad effects on health because of various addictions like smoking, tobacco chewing, alcohol consumption and drugs.

Conclusions: Educational intervention in the form of interactive sessions had a positive effect on the knowledge and perception of adolescents regarding nutrition, reproductive health and hygiene, body image, bad touch, addiction and psychological problems.

(Key words: Adolescent nutrition, Reproductive health, Bad touch, Health education)

\section{Introduction}

Adolescence is defined by the World Health Organisation (WHO) as the age group of children from 10 to 19 years ${ }^{1}$. Globally, adolescents aged 10 19 years are estimated to be 1.2 billion with 6.3 million deaths, $26 \%$ in the South-East Asia Region in $2015^{2}$. In India there are about 242 million adolescents, accounting for $22 \%$ of its population ${ }^{3}$. Health challenges for adolescents include pregnancy, sexually transmitted infections, reproductive tract infections, under-nutrition, anaemia, substance abuse and injuries ${ }^{4}$. To overcome these challenges, the Indian Government included Adolescent Reproductive and Sexual Health as a key technical strategy under the National Reproductive and Child Health II programme ${ }^{4}$. In developing countries, including India, many studies suggest that adolescents have misconceptions about reproductive health and pubertal changes because they do not have access to correct information and proper health education ${ }^{5}$. Adolescence is a suitable time to learn about healthy diets, consequences of alcohol and substance abuse, resisting peer pressure and bullying, healthy sexuality, sexual violence, respect for human rights, and promotion of gender equality $^{6}$. A recent study from Varanasi concluded that knowledge of school-going adolescents was weak about pubertal changes and reproductive 
health issues and that adolescents studying in Hindi medium schools require a more formal health and sex education programme in the school curriculum as compared to adolescents studying in English medium schools ${ }^{7}$. A few studies from developing countries found that sexual reproductive health knowledge of the school-going rural adolescents was fair and few misconceptions existed but after the adolescent health education interventional programme it was seen that the adolescents in the urban area obtained higher scores on adolescent reproductive health knowledge than those in the rural area ${ }^{8,9}$.

It is of paramount importance to give the adolescents information regarding the physical, biological (sexual), psychological and social changes they undergo during this period with special emphasis on sexual reproductive health. Present study was undertaken to access the knowledge about pubertal changes and reproductive health issues of the school-going adolescents from a rural Hindi medium school and see the effectiveness of a health education interventional programme in improving it.

\section{Objectives}

1. To impart correct information on all aspects of adolescent health, like nutrition, reproductive health, good hygienic practices, safe sex, sexually transmitted infections, image building, preventing drug addiction, smoking and substance abuse to adolescents in a rural part of central India.

2. To assess the effectiveness of a health education interventional programme in improving the knowledge and perception of adolescent students about nutrition, reproductive health, sexual and substance abuse and psychosocial problems.

\section{Method}

A study was conducted among adolescent students of $5^{\text {th }}$ to $9^{\text {th }}$ standard (10 -16 years age group) of a Hindi medium school cum hostel located in rural region in Wardha district of Maharashtra, India. It was a prospective interventional study and a health education interventional programme was conducted. The school selection was done based on rural area school, Hindi medium and permission from school authorities to conduct the study. Study was conducted from September - December 2018. A team of consultants from the Paediatric Department of Acharya Vinoba Bhave rural hospital conducted this study. Total of seven researchers conducted the health education interventional programme; all researchers were female paediatricians in age group of 35-65 years and had special interest in the field of adolescent health.
Calculation of sample size: This was determined by using the formula

$n=\left[\operatorname{DEFF}^{*} \mathrm{~Np}(1-\mathrm{p})\right] /\left[\left(\mathrm{d}^{2} / \mathrm{Z}^{2}{ }_{1-\alpha / 2} *(\mathrm{~N}-1)+\mathrm{p} *(1-\mathrm{p})\right]\right.$

By considering the population size $(\mathrm{N})$ : 5000; hypothesized \% frequency of outcome (p) of 0.50 , margin of error (d) of 5\%, Design effect $(D E F F): 1$ and confidence interval (CI) of $95 \%$, the calculated sample size was 372 .

Sampling method: Non probability purposive sampling was used

Eligibility criteria: Students of $5^{\text {th }}$ to $9^{\text {th }}$ standard who gave consent to be included in the study and had no visual or hearing disability and who attended the health education interventional programme were included in the study

A total of 401 adolescent students, both boys and girls, were included in the study. Students who were absent on the day when pre-test, workshop and posttest were conducted were not included in the study. A pre-designed, pre-validated structured questionnaire was given to the students at the beginning, as a pre-test in Hindi language, before the health education and awareness sessions, to know their awareness regarding adolescent health. Twenty six questions were asked on 5 themes, namely, nutrition and health, body image, menstrual hygiene and reproductive health, sexual abuse and psychosocial problems, with 4-5 questions in each theme. The questions were close-ended, true or false, yes or no type and multiple-choice questions. These pretest questionnaires, with answers written by adolescents, were collected. After pre-test health education and awareness, workshops were conducted, based on a pre-designed, pre-validated teaching module and various topics, based on the same five themes used in the pre-test, were discussed by the consultants with all adolescents, both boys and girls, included in the study, in interactive lecture sessions of one hour with the help of audio-visual aids like power point presentations and charts. In each interactive lecture session, approximately 30 students participated. The topics that were discussed in these interactive sessions were nutrition, body image, reproductive health, sexual abuse, substance abuse and psycho-social problems in adolescence. This was followed by a focus group discussion of girls and boys in different groups with a consultant researcher as facilitator and another as a scribe or note-taker. The focus group discussion had two points common for boys as well as girls' groups but for boys' group nocturnal emissions, masturbation and safe sex were discussed whereas for girls' group menstrual hygiene and safe sex were discussed. The main objective of separate focus group discussions for boys and girls was that they could open out about the issues discussed and participate without anxiety. A post-test was conducted at the end to assess the knowledge of the study participants using the same questionnaire used for the pre-test. Same process of conducting pre-test 
followed by health education and awareness workshop interactive sessions, followed by focus group discussion and post-test at end was adopted for adolescents of each class from $5^{\text {th }}$ to $9^{\text {th }}$ standard with the same consultant researchers conducting the interactive lecture sessions to minimize bias.

The pre-test and post-test questionnaires answered by the students were collected and analysed. The students were instructed that they should not disclose their identity on the answered questionnaires so that they would attempt all questions without anxiety. The response rate was $100 \%$ both for pre-test and post-test for each question. The number of correct responses for each question in pre-test and post-test were calculated and percentage derived. The data in the form of pre- and post-test questionnaire and notes taken during focus group discussion were collected.

Ethical Issues: Ethical clearance for the study was obtained from the Institutional Ethics Committee of the Jawaharlal Nehru Medical College, Sawangi, Wardha, Maharashtra, India (IEC approval letter number

DMIMS(DU)/IEC/2018-19/7484). Informed written assent was taken from the adolescent students before including them in the study. The Principal of the school and their management committee authorities gave permission to conduct the study. The study did not pose any financial burden on the participants.

Statistical analysis: The responses in the questionnaire were entered in the MS Office Excel sheet and analysis of data was done using STATA 10 version software. Percentages, Pearson Chisquare test and two sample t-test with equal variance were applied to calculate $\mathrm{p}$-value and for qualitative data content analysis was done.

\section{Results}

In the present study 401 adolescents, 200 males and 201 females, in age group of 10-15 years were included (Table 1). Maximum number of adolescents (80\%) were in 12-14 year age group and almost equal gender distribution was seen amongst adolescents included in the study.

Table 1: Age and gender distribution

\begin{tabular}{|c|c|c|c|c|}
\hline Age (years) & Male & Female & Total & Percentage \\
\hline 10 & 15 & 15 & 30 & 07.5 \\
\hline 11 & 16 & 17 & 33 & 08.2 \\
\hline 12 & 59 & 57 & 116 & 28.9 \\
\hline 13 & 48 & 52 & 100 & 24.9 \\
\hline 14 & 55 & 50 & 105 & 26.2 \\
\hline 15 & 7 & 10 & 17 & 04.2 \\
\hline Total & 200 & 201 & 401 & 100.0 \\
\hline Percentage & 49.9 & 50.1 & & \\
\hline
\end{tabular}

In knowledge and perception regarding nutrition and health, body and self-image, menstrual hygiene and reproductive health, awareness about sexual abuse and psychological problems of adolescence there was statistically significant improvement after the educational intervention as indicated by the pre-test and post-test scores (Tables 2, 3, 4, 5 and 6).

Table 2: Knowledge regarding nutrition and health

\begin{tabular}{|l|c|c|c|c|c|}
\hline \multirow{2}{*}{ Question } & \multicolumn{2}{c|}{ Pre test } & \multicolumn{2}{c|}{ Post test } & p-value \\
\cline { 2 - 6 } & $\begin{array}{c}\text { Correct response } \\
\text { to question }\end{array}$ & $\mathbf{\%}$ & $\begin{array}{c}\text { Correct response } \\
\text { to question }\end{array}$ & $\mathbf{\%}$ & \\
\hline Which food item is rich in protein? & 290 & 72.3 & 350 & 87.2 & 0.000 \\
\hline Improper hand washing causes which disease? & 87 & 21.6 & 136 & 33.9 & 0.000 \\
\hline What does iron deficiency cause? & 283 & 70.5 & 348 & 86.7 & 0.000 \\
\hline Which vitamin deficiency causes night blindness? & 108 & 26.9 & 179 & 44.3 & 0.000 \\
\hline Which vitamin is essential for strong bones? & 142 & 35.4 & 262 & 65.3 & 0.000 \\
\hline
\end{tabular}

Table 3: Knowledge regarding body image and self-image

\begin{tabular}{|l|c|c|c|c|c|}
\hline \multicolumn{1}{|c|}{ Question } & \multicolumn{2}{c|}{ Pre test } & \multicolumn{2}{c|}{ Post test } & p-value \\
\cline { 2 - 6 } & $\begin{array}{c}\text { Positive response } \\
\text { to question }\end{array}$ & $\mathbf{\%}$ & $\begin{array}{c}\text { Positive response } \\
\text { to question }\end{array}$ & $\mathbf{\%}$ & \\
\hline How can you promote good health and beauty? & 312 & 77.8 & 386 & 96.2 & 0.000 \\
\hline $\begin{array}{l}\text { Which is the most important criterion for good } \\
\text { body \& self-image? }\end{array}$ & 306 & 76.3 & 380 & 94.7 & 0.000 \\
\hline Which is the best way to prevent and treat acne? & 276 & 68.8 & 361 & 90.0 & 0.000 \\
\hline What is the adolescent age group? & 87 & 21.6 & 206 & 64.8 & 0.000 \\
\hline
\end{tabular}


Table 4: Knowledge regarding menstrual hygiene and reproductive health

\begin{tabular}{|l|c|c|c|c|c|}
\hline \multirow{2}{*}{ Question } & \multicolumn{2}{c|}{ Pre test } & \multicolumn{2}{c|}{ Post test } & p- value \\
\cline { 2 - 6 } & $\begin{array}{c}\text { Positive response } \\
\text { to question }\end{array}$ & $\mathbf{\%}$ & $\begin{array}{c}\text { Positive response } \\
\text { to question }\end{array}$ & $\mathbf{\%}$ & \\
\hline What is the mode of transmission of HIV? & 112 & 27.9 & 175 & 43.6 & 0.000 \\
\hline HIV is a sexually transmitted disease: True/False & 208 & 51.4 & 233 & 58.1 & 0.000 \\
\hline Nocturnal emission causes weakness: True/False & 170 & 42.3 & 209 & 52.1 & 0.000 \\
\hline $\begin{array}{l}\text { Is masturbation in public places socially } \\
\text { acceptable? Yes/No }\end{array}$ & 170 & 42.3 & 253 & 62.8 & 0.000 \\
\hline What is the duration of menstrual cycle in girls? & 171 & 42.6 & 245 & 61.0 & 0.000 \\
\hline What is the minimum age to conceive? & 104 & 25.9 & 149 & 37.1 & 0.000 \\
\hline
\end{tabular}

Table 5: Awareness about sexual abuse

\begin{tabular}{|l|c|c|c|c|c|}
\hline \multicolumn{1}{|c}{ Question } & \multicolumn{2}{c|}{ Pre test } & \multicolumn{2}{c|}{ Post test } & p-value \\
\cline { 2 - 6 } & $\begin{array}{c}\text { Positive response } \\
\text { to question }\end{array}$ & $\mathbf{\%}$ & $\begin{array}{c}\text { Positive response } \\
\text { to question }\end{array}$ & $\mathbf{\%}$ & \\
\hline What is bad touch? & 290 & 72.3 & 350 & 87.2 & 0.000 \\
\hline Touching your private parts: Right/Wrong & 306 & 76.3 & 361 & 90.0 & 0.000 \\
\hline If you experience bad touch is it your fault? & 200 & 49.8 & 251 & 62.5 & 0.000 \\
\hline $\begin{array}{l}\text { Whom should you inform after experiencing bad } \\
\text { touch? }\end{array}$ & 348 & 86.7 & 383 & 95.5 & 0.000 \\
\hline $\begin{array}{l}\text { What will you do if someone offers you gifts } \\
\text { repeatedly? }\end{array}$ & 322 & 80.2 & 367 & 91.5 & 0.000 \\
\hline
\end{tabular}

Table 6: Awareness of adolescent psychological problems

\begin{tabular}{|l|c|c|c|c|c|}
\hline \multicolumn{1}{|c}{ Question } & \multicolumn{2}{c|}{ Pre test } & \multicolumn{2}{c|}{ Post test } & p- value \\
\cline { 2 - 6 } & $\begin{array}{c}\text { Positive response } \\
\text { to question }\end{array}$ & $\mathbf{\%}$ & $\begin{array}{c}\text { Positive response } \\
\text { to question }\end{array}$ & $\mathbf{\%}$ & \\
\hline Do adolescent need proper guidance: Yes/No & 358 & 89.2 & 395 & 98.5 & 0.002 \\
\hline What is the disadvantage of addiction? & 181 & 45.1 & 270 & 67.3 & 0.000 \\
\hline How can one try to become addiction free? & 77 & 18.9 & 176 & 43.8 & 0.000 \\
\hline How to restrict mobile addiction? & 173 & 43.1 & 277 & 69.0 & 0.000 \\
\hline What is the correct way to face failure? & 302 & 75.3 & 361 & 90.0 & 0.000 \\
\hline $\begin{array}{l}\text { Adolescent psychological problems are: } \\
\text { treatable/non treatable }\end{array}$ & 291 & 72.5 & 370 & 92.2 & 0.013 \\
\hline
\end{tabular}

Many adolescents knew before educational intervention the diet rich in proteins, and that iron deficiency causes anaemia but many were not aware about diseases caused by improper hand washing and were not aware about diseases caused by vitamin deficiencies. Adolescents had good knowledge about promotion of good health and beauty, major contributors to good body image and self-image, prevention of acne but many had no idea about adolescent age group. They knew that the human immunodeficiency virus (HIV) was a sexually transmitted infection (STI) but had little knowledge about other modes of transmission of HIV. About $42 \%$ adolescent girls and boys knew about night emissions, masturbation and duration of menstrual cycle and that night emission does not cause weakness and masturbation in public places is wrong but few knew about the ideal age to conceive. Their awareness regarding bad touch and how to respond if they experience it was good as indicated by pre-test scores except that they were not sure about the fact that experiencing bad touch was not their fault. As indicated by pre-test scores, the majority of adolescents thought that there was a need for proper guidance to adolescents, they had knowledge that adolescent psychological problems were treatable and knew how to respond to failures in a positive manner. But very few of them had knowledge about disadvantages of addiction, how to overcome addiction of drug, smoking, alcohol and mobile addiction as indicated by low pre-test scores.

During focus group discussions conducted separately for girls and boys after educational intervention, it was observed on qualitative analysis that they had knowledge about bad effects on health of adolescents and to society due to various addictions like smoking, tobacco chewing, alcohol consumption and drugs. Girls knew that the minimum age above which they can marry was 18 years and boys knew they can marry only after 21 years of age. All girls used sterile cotton pads during menstrual bleeding and none of them used cloth. The girls had knowledge about frequent changing of pads and proper disposal of used pads (Tables 7 and 8). 
Table 7: Qualitative analysis of focus group discussions of female adolescent students

\begin{tabular}{|c|l|l|}
\hline Serial No. & \multicolumn{1}{|c|}{ Theme } & \multicolumn{1}{c|}{ Response } \\
\hline 1. & $\begin{array}{l}\text { Awareness about addictions and their } \\
\text { bad effects on health }\end{array}$ & $\begin{array}{l}\text { Majority girls felt addictions to smoking, tobacco chewing, } \\
\text { alcohol consumption and drugs was bad and knew their harmful } \\
\text { effects to adolescents and society. }\end{array}$ \\
\hline 2. & $\begin{array}{l}\text { Using sterile cotton pads during } \\
\text { menstrual bleeding is more hygienic }\end{array}$ & $\begin{array}{l}\text { Majority girls agreed to use sterile pads during menstrual bleeding. } \\
\text { None of them used cloth }\end{array}$ \\
\hline 3. & Changing of pads and their disposal & $\begin{array}{l}\text { Majority thought that pads should be changed frequently } \\
\text { Majority of girls had knowledge about proper method of disposal } \\
\text { of used pads }\end{array}$ \\
\hline 4. & Ideal minimum age to get married & Girls knew about minimum age above which girls can marry \\
\hline
\end{tabular}

Table 8: Qualitative analysis of focus group discussions of male adolescent students

\begin{tabular}{|c|l|l|}
\hline Serial No, & \multicolumn{1}{|c|}{ Theme } & \multicolumn{1}{c|}{ Response } \\
\hline 1. & $\begin{array}{l}\text { Awareness about addictions and their } \\
\text { bad effects on health }\end{array}$ & $\begin{array}{l}\text { Majority boys felt addictions to smoking, tobacco chewing, } \\
\text { alcohol consumption and drugs was bad and knew their } \\
\text { harmful effects to adolescents and society }\end{array}$ \\
\hline 2. & Ideal minimum age to get married & Boys knew about minimum age after which boys can marry \\
\hline
\end{tabular}

\section{Discussion}

Despite improvements in many settings, the adolescent health challenge is greater today than 25 years ago ${ }^{6}$. A study in Lancet ${ }^{6}$ reported indicators for adolescent's health in 188 countries and 7 locations from 1990 to 2016. This can be considered a global estimate. According to this, the number of overweight/obese adolescents doubled and number of adolescents with anaemia increased by $20 \%$.

In a study by Sharma $\mathrm{V}$, et $a l^{10}$ regarding impact of educational intervention on knowledge about nutrition of adolescent girls, 32\% girls knew the cause of night blindness compared to $27 \%$ in present study, but with post-educational intervention, the knowledge of adolescent girls improved to $72 \%$ as compared to $44 \%$ in present study. This could be due to themes other than nutrition being included in the educational intervention. Knowledge of iron deficiency leading to anaemia increased from $22 \%$ to $64 \%$ in study by Sharma $\mathrm{V}$, et $a l^{10}$ whereas in present study it increased from $71 \%$ to $87 \%$, indicating that pre-test knowledge in adolescents about iron deficiency was more in present study. Knowledge regarding importance of vitamin D for healthy bones was $26 \%$ in study by Sharma V, et al ${ }^{10}$ and was $35 \%$ in present study and post intervention it increased to $58 \%$ which is comparable to $63 \%$ in present study. Causes of acne were known to $56 \%$ adolescent girls as compared $69 \%$ in present study and after intervention it increased to $84 \%$ and $90 \%$ respectively which is comparable.

Shrivastav $\mathrm{U}$, et $a l^{7}$ in their study on school-going adolescents, regarding knowledge and perception about pubertal changes and reproductive health, found that $66 \%$ girls knew the suitable age for childbearing to be more than 21 years. Knowledge of childbearing age in girls was found to be $70 \%$ in study by Kishore $\mathrm{D}$, et $a l^{11}$. However, in our study only $26 \%$ students, inclusive of both boys and girls, knew minimum ideal age for childbearing and this low score could be due to boys also being assessed along with girls. In a study by Kishore $\mathrm{D}$, et $a l^{11}$ on 150 adolescent girls in rural Bangalore, their baseline knowledge regarding transmission and prevention of HIV was only $25 \%$, whereas in present study it was $51 \%$ but, in this study both girls and boys were included. Another study by Viero VSF, et $a l^{12}$ found $57 \%$ adolescent boys and girls included had baseline knowledge of HIV which is similar to present study whereas in a study by Dogra A, et al ${ }^{13}$ $79 \%$ girls knew that HIV was transmitted by sexual contact which was higher as compared to present study. Similarly, in study by Phulambrikar RM, et $a l^{14} 74 \%$ girls knew about transmission of HIV.

One limitation of the study is that it was conducted in only one school in rural central India and thus does not represent a large population. The study design was such that no comparison was done between intervention and control group. Attitudinal changes could not be assessed as the duration of the study was short. More number of such educational interventions should be conducted in a large number of schools in the rural sector and of long duration to assess attitudinal change in the students. Adolescents should be educated about pubertal changes occurring in human body, nutrition, psycho-social problems, reproductive health and sexually transmitted infections by paediatricians, doctors, teachers and parents, from pre-adolescent age till they mature into an adult. This will definitely bring about an attitudinal change in adolescents and lay a foundation for a healthy society.

\section{Conclusions}

Educational intervention in the form of interactive sessions with audio-visuals conducted by consultant paediatricians had a positive effect on knowledge and perception of adolescent boys and girls included in the study regarding adolescent nutrition, reproductive health and hygiene, body image, bad touch, addiction and psychological problems. 


\section{References}

1. Final report: Regional Working Group on Health Needs of Adolescents, Manila Philippines, 12-18 March 1980. Manila, Philippines: Regional Office for the Western Pacific, 1980. 30 p. $\mathrm{ICP} / \mathrm{MCH} / 005$

2. Strategic Guidance on Accelerating Actions for Adolescent Health in SouthEast Asia Region (2018-2022). New Delhi: World Health Organization, Regional Office for South-East Asia; 2018. Licence: CC BY-NC-SA 3.0 IGO.

3. Adolescents in India: A desk review of existing evidence and behaviours, programmes and policies. 2013. New Delhi: Population Council \& UNICEF.UNICEF.

4. Chauhan MG, Solanki HM, Patel HM, Singh MP. A study of reproductive health needs of adolescent girls of UHTC field practice area, Government Medical College, Bhavnagar. National Journal of Integrated Research Medicine 2015; 6: 158.

5. Mohammadi MR, Mohammad K, Farahani FK et al. Reproductive knowledge, attitudes and behavior among adolescent males in Tehran, Iran. International Family Planning Perspectives 2006; 35-44.

6. Azzopardi PS, Hearps SJC, Francis KL, Kennedy EC, Mokdad AH, Kassebaum $\mathrm{Nj}$, et al. Progress in adolescent health and wellbeing: tracking 12 headline indicators for 195 countries and territories, 19902016. Lancet 2019; 393(10176): 1101-18. https://doi.org/10.1016/S01406736(18)32 427-9

7. Srivastava U, Singh KK. Exploring knowledge and perceptions of school adolescents regarding pubertal changes and reproductive health. Indian Journal of Youth and Adolescent Health 2017; 4(1): 26-35.

https://doi.org/10.24321/2349.2880.20170 5

8. Abiodun O, Olu-Abiodun O, Ani F, Sotunsa O. Sexual and reproductive health knowledge and service utilization among in-school rural adolescents in Nigeria. Journal of AIDS \& Clinical Research 2016; 7(6): 1-8. https://doi.org/10.4172/21556113.100057 6

9. Susanto T, Rahmawati I, Wantiyah. A community-based friendly health clinic: An initiative adolescent reproductive health project in the rural and urban areas of Indonesia. International Journal of Nursing Sciences 2016; 3: 371-8. https://doi.org/10.1016/j.ijnss.2016.11.006

10. Sharma V, Singh V. Impact of education intervention on nutrition knowledge of adolescent girls. International Journal of Applied and Natural Sciences 2017; 6(5): 117-22.

11. Kishor D, Madaiah M, Munipapanna S, Sonnappa SD. Effectiveness of adolescent health education among secondary and senior secondary school girls in rural Bangalore. International Journal of Community Medicine and Public Health. 2019; 6(10): 4336-43.

https://doi.org/10.18203/23946040.ijcmph 20194491

12. Viero VSF, Farias JM, Ferraz F, Simões PW, Martins JA, Ceretta LB. Health education with adolescents: analysis of knowledge acquisition on health topics. Esc Anna Nery 2015; 19(3): 484-90. https://doi.org/10.5935/14148145.201500 64

13. Dogra A, Menia V, Pandita K. Knowledge, attitude, and practice study of adolescent girls about safe sexual practices. International Journal of Scientific Study 2019; 7(8): 77-80.

14. Phulambrikar RM, Kharde AL, Mahavarakar VN, Phalke DB, Phalke VD. Effectiveness of interventional reproductive and sexual health education among school going adolescent girls in rural area. Indian Journal of Community Medicine 2019; 44: 378-82. https://doi.org/10.4103/ijcm.IJCM_155_1 9

PMid: 31802804 PMCid: PMC6881892 